\title{
MENAKAR KEMAMPUAN BERPIKIR TINGKAT TINGGI CALON GURU MATEMATIKA MELALUI LEVEL HOTS MARZANO
}

\author{
Ega Gradini, Firmansyah B, Julia Noviani \\ STAIN Gajah Putih \\ e-mail: ega.gradini@gmail.com/egagradini@stain-gp.ac.id
}

\begin{abstract}
ABSTRAK
Makalah ini bertujuan untuk menakar kemampuan berpikir tingkat tinggi calon guru Matematika. Penulis menggunakan level HOTS Marzano yang terbagi dalam lima dimensi kemampuan berpikir; (1)pengambilan keputusan, (2)Pemecahan masalah, (3)Analisis kesalahan, (4)abstraksi, dan (5) analisis dan klasifikasi perspektif. Instrument yang digunakan diadaptasi dari Marzano Rubrics for Spesific task or Situations (1993). Penelitian ini merupakan penelitian kuantitatif dengan melibatkan 34 mahasiswa program studi Tadris Matematika, STAIN Gajah Putih. Hasil penelitian menunjukkan bahwa kemampuan berpikir tingkat tinggi calon guru Matematika berada pada level menengah dan rendah.
\end{abstract}

Kata Kunci : HOTS, Level Marzano, kemampuan berpikir

\begin{abstract}
This paper aims to measure students' high-level thinking skills through the level of pre-service mathematics teachers. The author used the Marzano HOTS level which is divided into five dimensions of thinking ability; (1) decision making, (2) problem solving, (3) error analysis, (4) abstraction, and (5) perspective analysis and classification. The instrument used was adapted from Marzano Rubrics for Specific Tasks or Situations (1993). This research is a quantitative research that involved 53 students of the Mathematics Education Department, STAIN Gajah Putih. The results of the study indicate that the ability to think on high-level of the pre-service teacher are at the moderate and low levels.
\end{abstract}

Keywords: HOTS, Marzano Level, Thinking Skills

\section{PENDAHULUAN}

Perubahan penting dalam pengajaran matematika perlu dilakukan untuk mengakomodir perubahan demografi dan siswa yang terus berlanjut dalam kelas matematika. Matematika bukan lagi sebagai alat (tool) tetapi aktivitas manusia (human activity). Oleh karena itu sangat penting mengajarkan matematika sebagai aktivitas yang relevan dengan kondisi riil di masyarakat. Beberapa ilmuwan telah mengembangkan teori pedagogi yang relevan dan meneliti proses belajar-mengajar dalam paradigma kritis dan melalui hubungan eksplisit antara kehidupan riil siswa dan materi pelajaran sekolah. Torres-Velasquez dan Lobo (2004) mengusulkan agar guru mengkontekstualisasikan pembelajaran matematika dengan menghubungkan konten matematika dengan budaya dan pengalaman kehidupan nyata siswa. Sayangnya, pembelajaran matematika procedural masih membayangi pengajaran matematika di Indonesia. Siswa hanya bergantung pada soal matematika dan bagaimana prosedur penyelesaiannya. Siswa tidak menemukan adanya makna matematika dalam kehidupan sehari-hari yang berimplikasi pada kemampuan literasi siswa Indonesia. Siswa Indonesia terbiasa berpikir pada jajaran rendah atau dikenal dengan Lower Order Thinking Skills (LOTS). Fenomena ini merupakan salah satu penyebab perubahan kurikulum nasional yang sebelumnya Kurikulum Tingkat Satuan Pendidikan (KTSP) menjadi Kurikulum 2013.

Kemampuan berpikir tingkat tinggi atau dikenal juga dengan Higher Order Thinking Skills (HOTS) merupakan tuntutan Kurikulum 2013. Badan Standar Nasional Pendidikan (BSNP) telah menyusun Asessmen Nasional Indonesia yang 
menekankan daya saing anak-anak Indonesia dalam kecakapan hidup abad 21 (21 st century lifeskills). Asesmen Nasional Indonesia diarahkan kepada model asesmen yang menuntut kemampuan berpikir yang tidak hanya mengingat (recall), menyatakan kembali (restate), atau merujuk tanpa melakukan pengolahan (recite). Kebijakan Kementerian Pendidikan dan Kebudayaan dinilai tepat untuk menerapkan soal yang mendorong peserta didik untuk melakukan penalaran, tidak hanya sekedar pemahaman dan penerapan. Asesmen modal HOTS dilaksanakan untuk memunculkan hakikat pembelajaran matematika yang selama ini dirasa kurang bermakna. Asessmen model HOTS juga dilakukan untuk mengejar keterbelakangan bangsa Indonesia di tingkat internasional, khususnya yang terkait dengan hasil Program for International Student Assessment (PISA) yang diselenggarakan tiga tahun sekali dan Trends in International Mathematics and Science Study (TIMSS) yang diselenggarakan 4 tahun sekali. BSNP tidak menafikan kenyataan bahwa kemampuan guru-guru dalam menyusun soal model HOTS masih perlu ditingkatkan. Namun tidak dipungkiri ada prinsip-prinsip HOTS yang belum sepenuhnya diterapkan dalam menyusun soal ujian. Selain itu, guru dan siswa tidak terbiasa mengerjakan soal HOTS meskipun soal-soal HOTS telah lama muncul pada buku ajar/teks Matematika di sekolah. Oleh karena itu penerapan soal model HOTS dalam UN perlu diimbangi dengan peningkatan kemampuan guru dan siswa dalam proses belajar mengajar. Hingga kini, telah dilakukan beberapa pelatihan penyusunan soal HOTS namun tidak dilakukan secara berkala dan melibatkan banyak guru matematika, terutama guru matematika di Madrasah.

BSNP telah berkoordinasi dengan Balitbang Kementerian Pendidikan dan Kebudayaan bahwa untuk mendorong berkembangnya soal model HOTS ini, penskoran soal dilakukan dengan mempertimbangkan kompleksitas soal. Soal yang lebih kompleks diberi bobot yang lebih tinggi. Dengan demikian akan ada faktor pembeda antara siswa yang mampu menjawab soal model HOTS dan siswa yang hanya mampu menjawab soal yang mudah atau sedang.
Sehingga perlu dilakukan penyelarasan antara proses pembelajaran dan penilaian dengan mengacu kepada standar nasional pendidikan.

Terdapat beberapa tes internasional yang digunakan selain untuk evaluasi pendidikan secara global juga digunakan untuk mengetahui apakah Indonesia sudah mampu untuk bersaing dengan negara-negara di dunia, dan dimanakah posisi Indonesia diantara negara-negara di dunia, Dua diantara tes tersebut adalah Programme for International Student Asessment (PISA) dan Trends in International Mathematics and Science Study (TIMSS). Sejauh ini hasil PISA dan TIMSS tidak menunjukkan hasil yang memuaskan.

PISA menyajikan masalah-masalah matematika yang memuat Content, Contexts, dan Competencies. Masalah matematika yang disajikan berupa sebuah situasi di dunia nyata yang menyediakan konteks untuk menerapkan matematika. Untuk memecahkan masalah tersebut, siswa harus memiliki tingkat kemampuan yang meliputi konten matematika yang relevan. Hasil PISA 2015 menunjukkan beberapa perbaikan dalam keterampilan siswa Indonesia. Secara khusus, anak perempuan berperforma lebih baik daripada anak laki-laki dalam semua mata pelajaran: Sains, Bahasa, dan Matematika. Pada mata pelajaran Matematika, Indonesia berada di peringkat 62 dari 72 negara, sedikit mengalami peningkatan dibandingkan tahun 2013. Siswa Indonesia menempati peringkat kedua terendah dalam peringkat PISA 2013 (71), lebih buruk dari peringkat mereka di tahun 2009, saat Indonesia berada di peringkat ke57. Peningkatan kinerja anak perempuan telah membantu mengangkat ranking Indonesia. Namun, secara keseluruhan, kinerja siswa Indonesia (anak perempuan dan anak laki-laki) dalam sains, matematika dan membaca adalah salah satu yang terendah di antara negara-negara peserta PISA dengan peringkat rata-rata 62 dari 69 negara. (Tiga dari 72 penilaian melibatkan pengelompokan kota: Buenos Aires (Argentina), Beijing-Shanghai-JiangsuGuangdong (China) dan Hong Kong (China)). TIMSS adalah studi internasional yang mengukur kemampuan siswa di bidang matematika dan sains. TIMSS bertujuan 
untuk melihat bagaimana kurikulum yang dicanangkan oleh setiap negara diimplementasikan dan capaian siswa khususnya pada bidang matematika dan sains. TIMSS diselenggarakan setiap 4 tahun sekali dan dikoordinasikan oleh IEA (the International Association for the Evaluation of Educational Achievement). Indonesia berpartisipasi pada studi TIMSS sejak tahun
1999. Namun baru tahun 2015 target populasinya kelas 4 SD/MI. Secara umum, siswa Indonesia lemah di semua aspek konten maupun kognitif, baik untuk matematika maupun sains. Pada bidang Matematika, Indonesia berada pada posisi 47 dari 50 negara peserta. Namun diagnosa secara mendalam menemukan hal-hal yang sudah dikuasai juga hal-hal yang perlu mendapatkan perhatian lebih.
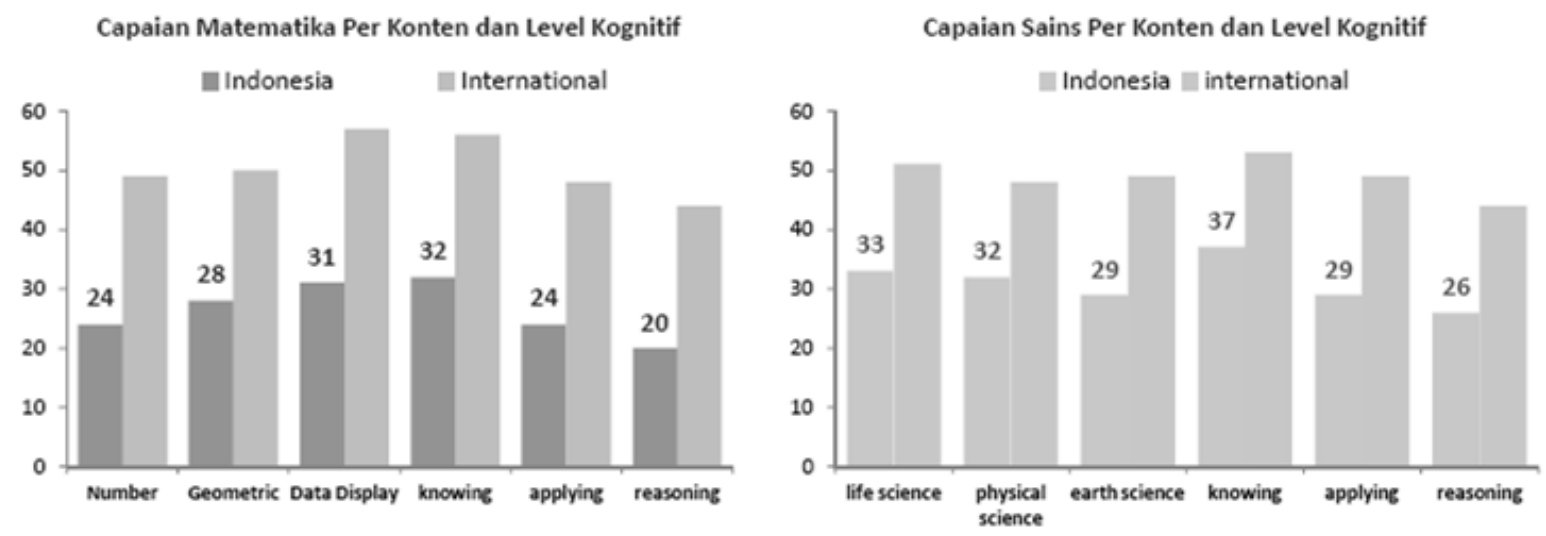

Gambar 1. Pencapaian siswa Indonesia dalam TIMSS

Di Indonesia, tes terstandarisasi yang digunakan untuk mengevaluasi kompetensi siswa Indonesia adalah Ujian Nasional (UN). Secara nasional, Nilai UN SMA /MA pada mata pelajaran Matematika menurun pada tahun 2018. Merosotnya nilai UN Matematika disinyalir disebabkan oleh (1)meningkatnya integritas pelaksanaan UNBK dan (2)munculnya soal HOTS pada soal UN. Di Kabupaten Aceh Tengah, nilai rata-rata UN pada matapelajaran Matematika juga turun dibandingkan 2 tahun sebelumnya, sebagaimana terlihat pada tabel berikut.

Tabel 1. Nilai Matapelajaran Matematika pada UNBK 2018 di Kab.Aceh Tengah

\begin{tabular}{ccc}
\hline Nilai Minimum & Nilai Maximum & Nilai Rata-Rata \\
\hline 16.53 & 47.91 & 27.98 \\
\hline
\end{tabular}

Peneliti mengkonfirmasi data ini melalui wawancara dengan guru Matematika di MAN 1 Takengon, SMA Negeri 1 Takengon, SMA Negeri 15 Takengon, dan SMA Negeri 2 Takengon. Ditemukan bahwa penyebab ketidakmampuan siswa menyelesaikan soal HOTS baik pada pembelajaran sehari hari maupun UN diantaranya:

(1) Soal UN disajikan dengan computer dan menggunakan beragam tipe soal yang berbeda sehingga integritas pelaksanaan UNBK lebih tinggi dibanding tahun sebelumnya
(2) Siswa tidak terbiasa mengerjakan soal HOTS

(3) Guru menghindari soal HOTS dalam pembelajaran

(4) Guru dan siswa memiliki persepsi yang sama, yakni soal HOTS adalah soal yang sulit

(5) Siswa dan guru tidak mengetahui bahwa soal HOTS akan dimasukkan dalam UN karena kisi-kisi soal yang diujiankan berbeda dengan yang diberitahukan oleh Kemdikbud. 


\section{KAJIAN PUSTAKA}

Higher Order Thinking Skill (HOTS) adalah salah satu komponen lifeskill abad 21 yang ditekankan dalam Kurikulum 2013 selain STEM (Science, Technology, Engineering, dan Mathematics) dan 4C (Communication; Collaboration; Critical Thinking and Problem Solving; Creativity and Innovation). Namun pelaksanaannya masih terbatas pada pemenuhan tuntutan Kurikulum 2013. Baik guru maupun siswa mendapatkan tantangan dalam penerapan soal HOTS dalam pembelajaran matematika di sekolah. HOTS menggabungkan kemampuan berpikir kreatif dan berpikir kritis.

Matematika merupakan ilmu yang berkaitan dengan konsep-konsep abstrak, oleh karena itu penyajian materi matematika dalam pembelajaran sering dikaitkan dengan kehidupan sehari-hari dengan tujuan agar peserta didik mampu menemukan konsep dan mengembangkan kemampuan matematikanya berdasarkan pengalaman atau pengetahuan yang telah dimiliki oleh peserta didik. Peserta didik dikatakan mampu menyelesaikan suatu masalah apabila peserta didik tersebut mampu menelaah suatu permasalahan dan mampu menggunakan pengetahuannya ke dalam situasi baru. Kemampuan inilah yang biasanya dikenal sebagai Higher Order Thinking Skills.

Higher Order Thinking Skill (HOTS) merupakan suatu proses berpikir peserta didik dalam level kognitif yang lebih tinggi yang dikembangkan dari berbagai konsep dan metode kognitif dan taksonomi pembelajaran seperti metode problem solving, taksonomi bloom, dan taksonomi pembelajaran, pengajaran, dan penilaian. HOTS ini meliputi di dalamnya kemampuan pemecahan masalah, kemampuan berpikir kreatif, berpikir kritis, kemampuan berargumen, dan kemampuan mengambil keputusan.

Berikut disajikan perkembangan makna kemampuan berpikir tingkat tinggi berdasarkan para ahli dari waktu ke waktu.

Tabel 2. Ragam Makna Kemampuan Berpikir Tingkat Tinggi

\begin{tabular}{|c|c|c|}
\hline Sumber & Tahun & Definisi \\
\hline King et al. & 1998 & $\begin{array}{l}\text { "mencakup pemikiran kritis, logis, reflektif, metakognitif, dan } \\
\text { kreatif. Diaktifkan ketika individu menghadapi masalah yang } \\
\text { tidak dikenal, ketidakpastian, pertanyaan, atau dilema." }\end{array}$ \\
\hline NCTM & 2000 & "Menyelesaikan masalah/soal rutin" \\
\hline $\begin{array}{l}\text { Anderson } \\
\text { Krathwohl }\end{array}$ & 2001 & Proses- analisis, evaluasi, dan kreasi \\
\hline $\begin{array}{l}\text { Lopez } \\
\text { Whittington }\end{array}$ & 2001 & $\begin{array}{l}\text { "terjadi ketika seseorang mengambil informasi baru dan } \\
\text { informasi yang disimpan dalam memori dan saling } \\
\text { berhubungan dan / atau mengatur ulang dan memperluas } \\
\text { informasi ini untuk mencapai tujuan atau menemukan } \\
\text { jawaban yang mungkin dalam situasi yang membingungkan." }\end{array}$ \\
\hline Weiss, E. & 2003 & $\begin{array}{l}\text { Kolaboratif, otentik, Tidak Terstruktur, Masalah yang } \\
\text { menantang }\end{array}$ \\
\hline Miri et al. & 2007 & $\begin{array}{l}\text { "... Strategi - pengaturan meta-tujuan; sedangkan pemikiran } \\
\text { kritis, sistemik, dan kreatif adalah taktik - kegiatan yang } \\
\text { diperlukan untuk mencapai tujuan yang dicanangkan." }\end{array}$ \\
\hline Rajendran, N. & 2008 & $\begin{array}{l}\text { Penggunaan pikiran yang diperluas untuk menghadapi } \\
\text { tantangan baru. }\end{array}$ \\
\hline Thompson, T. & 2008 & "Berpikir -Non Algoritmik" \\
\hline $\begin{array}{l}\text { Thomas, A. and } \\
\text { Thorne, G. }\end{array}$ & 2010 & $\begin{array}{l}\text { "... (Itu) membutuhkan pemikiran ke tingkat yang lebih tinggi } \\
\text { daripada hanya menyatakan kembali fakta. (Itu) } \\
\text { mengharuskan kita melakukan sesuatu dengan fakta. Kita } \\
\text { harus memahami mereka, menghubungkan mereka satu sama } \\
\text { lain, mengkategorikan mereka, memanipulasinya, } \\
\text { menyatukannya dengan cara baru atau baru, dan }\end{array}$ \\
\hline
\end{tabular}




\begin{tabular}{l|l|l}
\hline \multicolumn{1}{c|}{ Sumber } & Tahun & \multicolumn{1}{c}{ Definisi } \\
\hline Kruger, K. & 2013 & $\begin{array}{l}\text { menerapkannya ketika kita mencari solusi baru untuk masalah } \\
\text { baru." }\end{array}$ \\
\hline & $\begin{array}{l}\text { melibatkan "pembentukan konsep, pemikiran kritis, kreativitas } \\
\text { / brainstorming, penyelesaian masalah, representasi mental, } \\
\text { penggunaan aturan, penalaran, dan pemikiran logis." }\end{array}$ \\
\hline
\end{tabular}

Menurut taksonomi bloom, level kemampuan berpikir tingkat tinggi terletak pada level menganalisis (C4), mengevaluasi (C5), dan mencipta (C6). Bloom menyatakan bahwa terdapat dua level berpikir matematis siswa yaitu Lower Order Thinking Skills (LOTS) dan Higher Order Thinking Skills (HOTS). Maka dapat digolongkan level kemampuan menurut PISA dan Taksonomi Bloom.

Tabel 3. Kaitan Taksonomi Bloom, PISA, HOTS, dan LOTS

\begin{tabular}{|c|c|c|}
\hline Taksonomi Bloom & PISA & Level \\
\hline C6 & Level 6 & \\
\hline $\begin{array}{l}\text { Kemampuan memadukan unsur- } \\
\text { unsur menjadi sesuatu bentuk baru } \\
\text { yang utuh dan luas, atau membuatt } \\
\text { sesuatu yang orisinil }\end{array}$ & $\begin{array}{l}\text { Siswa menggunakan penalarannya } \\
\text { dalam menyelesaikan masalah } \\
\text { matematis, dapat membuat } \\
\text { generalisasi, merumuskan serta } \\
\text { mengkomunikasikan hasil temuannya }\end{array}$ & \multirow{5}{*}{$\begin{array}{l}\text { Higher Order } \\
\text { Thinking Skills } \\
\text { (HOTS) }\end{array}$} \\
\hline C5 & Level 5 & \\
\hline $\begin{array}{l}\text { Kemampuan menetapkan derajat } \\
\text { sesuatu berdasarkan norma, kriteria } \\
\text { atau patokan tertentu }\end{array}$ & $\begin{array}{l}\text { Siswa dapat bekerja dengan model } \\
\text { untuk situasi yang kompleks serta } \\
\text { dapat menyelesaikan masalah yang } \\
\text { rumit }\end{array}$ & \\
\hline $\mathrm{C4}$ & Level 4 & \\
\hline $\begin{array}{l}\text { Kemampuan memisahkan konsep } \\
\text { ke dalam beberapa komponen dan } \\
\text { menghubungkan satu sama lain } \\
\text { untuk memperoleh pemahaman } \\
\text { atas konsep secara utuh }\end{array}$ & $\begin{array}{l}\text { Siswa dapat bekerja secara efektif } \\
\text { dengan model dan dapat memilih } \\
\text { serta mengintegrasikan representasi }\end{array}$ & \\
\hline C3 & Level 3 & \\
\hline $\begin{array}{l}\text { Kemampuan melakukan sesuatu } \\
\text { dan mengaplikasikan konsep dalam } \\
\text { situasi tertentu }\end{array}$ & $\begin{array}{l}\text { Siswa dapat melaksanakan prosedur } \\
\text { dengan baik dalam menyelesaikan } \\
\text { soal serta dapat memilih strategi } \\
\text { pemecahan masalah }\end{array}$ & \multirow[t]{5}{*}{$\begin{array}{c}\text { Lower Order } \\
\text { Thinking Skills } \\
\text { (LOTS) }\end{array}$} \\
\hline C2 & Level 2 & \\
\hline $\begin{array}{l}\text { Kemampuan memahami instruksi } \\
\text { dan menegaskan ide atau konsep } \\
\text { yang telah diajarkan }\end{array}$ & $\begin{array}{l}\text { Siswa dapat menginterpretasikan } \\
\text { masalah dan menyelesaikannya } \\
\text { dengan rumus }\end{array}$ & \\
\hline C1 & Level 1 & \\
\hline $\begin{array}{l}\text { Kemampuan menyebutkan kembali } \\
\text { informasi yang tersimpan dalam } \\
\text { ingatan }\end{array}$ & $\begin{array}{l}\text { Siswa dapat menggunakan } \\
\text { pengetahuannya untuk } \\
\text { menyelesaikan soal rutin, dan dapat } \\
\text { menyelesaikan masalah yang } \\
\text { konteksnya umum. }\end{array}$ & \\
\hline
\end{tabular}




\section{METODE PENELITIAN}

Penelitian ini merupakan penelitian survey yang bertujuan untuk menakar kemampuan berpikir tingkat tinggi calon guru matematika. Sejumlah 34 mahasiswa program studi Tadris Matematika, STAIN Gajah Putih, dilibatkan sebagai responden penelitian. Penulis menggunakan level HOTS Marzano yang terbagi dalam lima dimensi kemampuan berpikir; (1)Pengambilan keputusan, (2)Pemecahan masalah, (3)Analisis kesalahan, (4)Abstraksi, dan
(5)Analisis dan klasifikasi perspektif. Instrument yang digunakan adalah Rubric of Complex Thinking, diadaptasi dari Marzano Rubrics for Spesific task or Situations (1993). Analisa data dilakukan dengan menghitung persentase dan frekuensi untuk menakar level HOTS Marzano dari 34 mahasiswa. Level kemampuan berpikir tingkat tinggi calon guru matematika lalu diukur dengan indicator berikut.

Tabel 4. Kategori level Kemampuan Berpikir Tingkat Tinggi (Heong, 2017)

\begin{tabular}{cl}
\hline Skor Rata-Rata & \multicolumn{1}{c}{ Kategori } \\
\hline $1.00-2.00$ & Rendah $($ Low $)$ \\
\hline $2.01-3.00$ & Menengah $($ Moderate $)$ \\
\hline $3.01-4.00$ & Tinggi $($ High $)$ \\
\hline
\end{tabular}

\section{HASIL PENELITIAN DAN PEMBAHASAN}

Berdasarkan hasil pengolahan data, diperoleh bahwa kemampuan berpikir tingkat tinggi calon guru matematika berada pada level "Menengah (Moderate)" dan "Rendah (Low)". Pemetaan kemampuan berpikir tingkat tinggi tersebut terlihat pada tabel berikut.

Tabel 5. Pemetaan Level Kemampuan Berpikir Tingkat Tinggi

Calon Guru Matematika

\begin{tabular}{lccc}
\hline \multicolumn{1}{c}{ Level Marzano } & Low & Moderate & Tinggi \\
\hline Comparing & $23.53 \%$ & $58.82 \%$ & $17.65 \%$ \\
\hline Classifying & $17.24 \%$ & $72.41 \%$ & $10.34 \%$ \\
\hline Inductive Reasoning & $82.35 \%$ & $14.71 \%$ & $2.94 \%$ \\
\hline Deductive Reasoning & $36.36 \%$ & $63.64 \%$ & $0.00 \%$ \\
\hline Analyzing Errors & $91.18 \%$ & $8.82 \%$ & $0.00 \%$ \\
\hline Constructing Support & $47.06 \%$ & $44.12 \%$ & $8.82 \%$ \\
\hline Analyzing Perspective & $82.35 \%$ & $17.65 \%$ & $0.00 \%$ \\
\hline Abstracting & $91.18 \%$ & $8.82 \%$ & $0.00 \%$ \\
\hline Decision Making & $70.59 \%$ & $29.41 \%$ & $0.00 \%$ \\
\hline Investigation & $85.29 \%$ & $14.71 \%$ & $0.00 \%$ \\
\hline Problem Solving & $79.41 \%$ & $20.59 \%$ & $0.00 \%$ \\
\hline Experimental inquiry & $100.00 \%$ & $0.00 \%$ & $0.00 \%$ \\
\hline Invention & $100.00 \%$ & $0.00 \%$ & $0.00 \%$ \\
\hline
\end{tabular}

Tabel 6. Level Kemampuan berpikir tingkat Tinggi Calon Guru Matematika (lanjutan)

\begin{tabular}{lll}
\hline \multicolumn{1}{c}{ Level Marzano } & Skor & \multicolumn{1}{c}{ Kategori } \\
\hline Comparing & 2.823529 & Menengah/Moderate \\
\hline Classifying & 2.426471 & Menengah/Moderate \\
\hline Inductive Reasoning & 1.794118 & Rendah/Low \\
\hline Deductive Reasoning & 2.382353 & Menengah/Moderate \\
\hline Analyzing Errors & 1.632353 & Rendah/Low \\
\hline Constructing Support & 2.382353 & Menengah/Moderate \\
\hline Analyzing Perspective & 1.764706 & Rendah/Low \\
\hline
\end{tabular}




\begin{tabular}{lcl}
\hline \multicolumn{1}{c}{ Level Marzano } & Skor & \multicolumn{1}{c}{ Kategori } \\
\hline Abstracting & 1.632353 & Rendah/Low \\
\hline Decision Making & 1.941176 & Rendah/Low \\
\hline Investigation & 1.720588 & Rendah/Low \\
\hline Problem Solving & 1.808824 & Rendah/Low \\
\hline Experimental inquiry & 1.5 & Rendah/Low \\
\hline Invention & 1.5 & Rendah/Low \\
\hline
\end{tabular}

Tabel 5 dan 6 menunjukkan bahwa pada kemampuan membandingkan (comparing), level kemampuan berpikir tingkat tinggi calon guru matematika berada pada kategori "menengah/moderate". Dari 34 responden, $23.53 \%$ calon guru matematika pada level rendah, 58.82\% pada level menengah, dan $17.65 \%$ pada level tinggi dalam mengidentifikasikan dan mengartikulasikan persamaan dan perbedaan antar objek. Pada kemampuan mengelompokkan (classifying), level kemampuan berpikir tingkat tinggi calon guru matematika berada pada kategori "Menengah/moderate". Dari 34 responden, $17.24 \%$ pada level rendah, $72.41 \%$ pada level menengah, dan $10.34 \%$ pada level tinggi dalam mengelompokkan benda/objek pada kategori terdefinisi/tertentu berdasarkan sifat-sifat mereka.

Pada kemampuan penalaran induktif (Inductive Reasoning), level kemampuan berpikir tingkat tinggi calon guru matematika berada pada kategori "rendah/low". Dari 34 responden, 82.35\% pada level rendah, $14.71 \%$ pada level menengah, dan $2.94 \%$ pada level tinggi dalam menyimpulkan generalisasi atau prinsip yang tidak diketahui dari suatu informasi atau observasi. Pada kemampuan penalaran deduktif (deductive reasoning), kemampuan berpikir tingkat tinggi calon guru matematika berada pada kategori "menengah/moderate". Dari 34 responden, $36.36 \%$ pada level rendah, dan $63.64 \%$ pada level menengah dalam menggunakan generalisasi dan prinsip untuk menyimpulkan kesimpulan tak tertulis tentang informasi atau situasi tertentu. Pada level Marzano ini, tidak ada responden yang berada pada level tinggi.

Pada kemampuan menganalisa kesalahan (analyzing errors), level kemampuan berpikir tingkat tinggi calon guru matematika berada pada kategori "rendah/low". Dari 34 responden, 91.18\% berada pada level rendah dan $8.82 \%$ berada pada level menengah dalam mengidentifikasi dan mengartikulasikan kesalahan berpikir. Pada level ini, tidak ada responden yang mampu mencapai level tinggi. Pada kemampuan mengkonstruksi dukungan (Constructing Support), level kemampuan berpikir tingkat tinggi calon guru matematika berada pada kategori "menengah/moderate". Dari 34 responden, $47.06 \%$ berada pada level rendah, $44.12 \%$ berada pada level menengah, dan $8.82 \%$ berada pada level tinggi dalam membangun sistem yang dukungan pernyataan.

Pada kemampuan menganalisis perspektif (Analyzing Perspective), level kemampuan berpikir tingkat tinggi calon guru matematika berada pada kategori "rendah/low". Dari 34 responden, $82.35 \%$ berada pada level rendah dan $17.65 \%$ berada pada level menengah dalam mengidentifikasi berbagai perspektif tentang suatu masalah dan memeriksa alasan atau logika di balik masing-masing pernyataan/masalah. Pada kemampuan abstraksi (abstraction), level kemampuan berpikir tingkat tinggi calon guru matematika berada pada kategori "rendah/low". Dari 34 responden, 91.18\% berada pada level rendah dan $8.82 \%$ berada pada level menengah dalam mengidentifikasi dan mengartikulasikan tema yang mendasari atau pola umum informasi.

Pada kemampuan pengambilan keputusan (decision making), level kemampuan berpikir tingkat tinggi calon guru matematika berada pada kategori "rendah/low". Dari 34 responden, 70.59\% berada pada level rendah dan $29.41 \%$ berada pada level menengah dalam menghasilkan dan menerapkan kriteria untuk memilih dari antara alternatif yang tampaknya setara. Pada kemampuan investigasi (investigation), level kemampuan berpikir tingkat tinggi 
calon guru matematika berada pada kategori "rendah/low". Dari 34 responden, 85.29\% berada pada level rendah dan $14.71 \%$ berada pada level menengah dalam mengidentifikasi dan menyelesaikan masalah yang menimbulkan kebingungan atau kontradiksi. Tidak ada responden yang mencapai level tinggi pada kemampuan ini.

Pada kemampuan memecahkan masalah (problem solving), level kemampuan berpikir tingkat tinggi calon guru matematika berada pada kategori "rendah/low". Dari 34 responden, 79.41\% berada pada level rendah dan $20.59 \%$ berada pada level menengah dalam mengatasi kendala atau membatasi kondisi yang menghalangi tujuan. Pada kemampuan inkuiri eksperimen (experimental inquiry), level kemampuan berpikir tingkat tinggi calon guru matematika berada pada kategori "rendah/low". Seluruh responden berada pada level rendah dalam menghasilkan dan menguji penjelasan dari fenomena yang diamati. Demikian halnya pada kemampuan penemuan (invention), level kemampuan berpikir tingkat tinggi calon guru matematika berada pada kategori "rendah/low". Seluruh responden berada pada level rendah dalam mengembangkan hasil atau proses unik yang memenuhi kebutuhan yang diterima/dirasakan.

\section{DAFTAR PUSTAKA}

Anderson, L. W., \& Krathwohl, D. R. 2010. Kerangka Landasan untuk Pembelajaran, Pengajaran, dan Asesmen. Yogyakarta: Pustaka Pelajar.

Baswedan, A. 2014. Gawat Darurat Pendidikan di Indonesia. Jakarta: Kementerian Pendidikan dan Kebudayaan Republik Indonesia.

Creswell, John W. 2010. Rancangan Penelitian Metode Campuran Modern. Pustaka Pelajar.

Gradini, E dan Firmansyah, F. 2018. Pembelajaran Matematika Berbasis Budaya Lokal untuk meningkatkan Kemampuan Literasi Matematis Siswa. Laporan Penelitian Kompetitif BOPTN. Unpublished. Takengon: STAIN Gajah Putih

Heong, Y.,Othman, W., Yunos, J., et all. The Level of Marzano Higher Order Thinking Skill among Technical
Education Students. International Journal of Science and Humanity, Vol 1, No 2, July 2011

King, F.J., Goodson, L., and Rohani, F. (1998) Higher-Order Thinking Skills: Definitions, Strategies, and Assessment. URL: http://www.cala.fsu.edu/files/higher order_thinking_skills.pdf.

Krathwohl, D. R. 2002. A revision of Bloom's taxonomy: An overview. Theory into practice 4

Kruger, K. (2013) Higher-Order Thinking. Hidden Sparks, Inc. New York, New York.

Anderson, L., and Krathwohl, D. (eds.) (2001). A Taxonomy for Learning, Teaching, and Assessing: A Revision of Bloom's Taxonomy of Educational Objectives. Longman Publishing Co., New York, New York.

Krulik, S., \& Rudnick, J. A. 1999. Innovative

Tasks to Improve Critical and Creative Thinking Skills. Developing Mathematical reasoning in Grades $K$ 12, 138-145.

Marzano,RJ. D. J. Pickering, D. E. Arredondo, G. J. Blackburn, R. S Brandt, C. A. Moffett, D. E. Paynter, J. E. Pollock, and J. S. Whisler, "Dimension of Learning Trainer's Manual," 2nd Ed, Aurora, Colorado: McREL, 1997

Marzano, R. (2000). Designing Effective Projects : Thinking Skills Frameworks Marzano's New Taxonomy

Marzano ' s New Taxonomy. Physicist. Retrieved from http://www.mendeley.com/research/ designingeffective-projectsthinking-skills-frameworksmarzano-s-new- taxonomymarzano-s-new-taxonomy/

Marzano, R. J., \& Kendall, J. S. (2007). The new taxonomy of educational objectives. The new taxonomy of educational objectives 2nd Ed (Vol.2nd).doi:10.1207/s15430421 tip4104

Torres-Velasquez, D., \& Lobo, G. (2004). Culturally responsive mathematics teaching and English language learners. Teaching Children Mathematics, 11, 249255. 